\title{
PANEL COINTEGRATION ANALYSIS IN DETERMINING RELATIONSHIP OF AGRICULTURAL COMMODITY AND OIL FUEL PRICE IN INDONESIA
}

\author{
Marizsa Herlina
}

Department of Statistics, Universitas Islam Bandung, Indonesia, marizsaherlina@gmail.com

\author{
Indonesian Journal of Statistics and Its Applications (elSSN:2599-0802) \\ Vol 4 No 2 (2020), 341 - 358
}

Copyright (C) 2020 Marizsa Herlina. This is an open-access article distributed under the Creative Commons Attribution License, which permits unrestricted use, distribution, and reproduction in any medium, provided the original work is properly cited.

\begin{abstract}
This paper contributes to explain the relationship between oil fuel prices, oil price, the exchange rates, and agricultural commodity prices in Indonesia by using panel cointegration. Thus, this paper studied the short- and long-run relationships between oil fuel prices, oil prices, exchange rates, and agricultural commodity prices using the panel cointegration and causality analysis on five main agricultural commodities in Indonesia (i.e. rice, beef, palm oil, red chili, and sugar). The study was conducted using weekly agricultural, oil fuel, oil prices, and exchange rates from October 2014 until May 2016. The results showed that the oil fuel prices and the exchange rate had a long-run impact on agricultural commodity prices. The direction of the causality had also been determined. The oil fuel prices, oil prices, and exchange rate altogether had a unidirectional Granger causality to all of the agricultural commodity prices except beef and palm oil prices in the long-run.
\end{abstract}

Keywords: agricultural price, causality relationship, exchange rate, oil fuel price, panel co-integration.

\section{Introduction}

Indonesia is a tropical country with fertile soils that can produce a varied range of agricultural commodities. A lot of Indonesian citizens make a living through the agricultural sector and almost half of the total labour force in Indonesia is working in this sector. Thus, the agriculture sector has become one of the most important sectors

\footnotetext{
${ }^{*}$ Received Mei 2020; Accepted Jul 2020; Published online on Jul 2020
} 
in Indonesia. Oil fuel has a very important link to every sector in Indonesia because it is one of the main energy sources. The agricultural sector depends on oil fuel a lot for the distribution of the commodities.

Several studies have been conducted on the relation between the energy market and the agricultural market (Abdlaziz et al., 2016; Ciaian \& Kancs, 2011; Harri et al., 2009; Kwon \& Koo, 2009; Nazlioglu \& Soytas, 2012; Prastowo et al., 2008; Yu et al., 2006; Zhang, 2008). Two different channels connect these two markets, one direct and the other indirect.

The indirect channel is, as we know, that oil fuel is an important input for agricultural commodities because it is used a lot in the agricultural commodities' production (fuel, fertilizers, and pesticides) and transportation and would have an impact on agricultural commodity prices. The direct channel, which has only been discovered lately, is the biofuel channel; the increasing demand for biofuel has just occurred recently due to the unsustainability of crude oil. The world has now become more interested in developing new sources of energy that are much more environmentally friendly and reduce the carbon footprint. Biofuels made from various agricultural commodities such as corn, soybean, and so on, have become popular alternative energy because of their sustainable traits. Thus, the price of agricultural commodities now also needs to adjust to the energy market. Agricultural commodities that provide the raw materials for biofuels show a rising demand as well as the price (Chen et al. 2010).

Numerous studies have attempted to discover the relationship between the energy and agricultural markets via the biofuels channel (Ciaian \& Kancs, 2011; Nazlioglu, 2011; Nazlioglu \& Soytas, 2012; Yu et al., 2006). Several studies (Nazlioglu, 2011; Yu et al., 2006; Zhang, 2008) supported the argument that in the linear case, the oil price had nothing to do with biomass ${ }^{\dagger}$ (neutrality hypothesis). The shortcomings of these studies were that they did not provide any theoretical basis about the relationship between fossil energy and biomass. Thus, Ciaian \& Kancs (2011) tried a different approach featuring a theoretical model of vertical market integration model between energy and biomass (de Gorter \& Drabik, 2016; Gardner, 2007) and They also consider the indirect channel from the energy market to the agricultural market. The finding of this study is that the biofuel channel seemed to have a stronger impact on agricultural commodities compared to the indirect channel. It is also shown that the oil has Granger causality in respect of the agricultural commodity prices but not vice versa in the long run.

Unfortunately, these findings might also face the problem of omitted variable bias from the exclusion of the exchange rate (Adämmer \& Bohl, 2015). The exchange rate is considered to be an important variable in the system because agricultural commodities are mostly traded in US Dollars. Because the exchange rate might play an important role in the system, it should not be ignored in the analysis. Harri et al., (2009) included the exchange rate in the system and studied the relationship between crude oil prices, exchange rates, and agricultural commodity prices in the US. This study found that there was a direct linkage between the oil and commodity prices (corn, soybeans, soybean oil, and cotton) and an indirect effect from the exchange

\footnotetext{
${ }^{\dagger}$ Biomass is plant source which is used for fuel directly or processed into biofuels. Biofuel products include ethanol, biodiesel and biogas.
} 
rate. Kwon \& Koo (2009) also included the exchange rate in analysing the relationship between energy in the US and food prices. They found that the exchange rate movements explained crude oil prices and vice versa while crude oil also has Granger causality in respect of the retail food. This means that the exchange rate is also an important key in explaining food inflation.

Taking the analysis to a different level, the follow-up study by Nazlioglu \& Soytas (2012) analysed the causality relationship between oil prices, the exchange rate, and the agricultural commodities prices by using more than 20 agricultural varieties in the panel cointegration. By accommodating both cross-section and time series dimensions, the panel method is said to be better than the time series analysis. The combination of cross-section and time series dimensions in this method provides greater statistical power in the test of panel cointegration. The results in the follow-up paper are that oil prices have unidirectional causality to agricultural prices and the dollar, while agricultural prices and the dollar has bi-directional causality (they have Granger causality in respect of each other). This result surprisingly contradicts the results from Nazlioglu (2011) which stated the linear causality support for the neutrality hypothesis. This probably happened because the panel method contained more information (cross-section and time series information). The inclusion of the exchange rate and a wider range of agricultural commodities is also considered to be an important reason for the contrasting results.

Therefore, this paper aims to study the relationship between oil fuel price, world oil price, exchange rates, and the agricultural commodity prices in Indonesia. Using the panel cointegration and causality analysis, this study will use a panel of five agricultural commodity prices which are considered as the most important agricultural commodities in Indonesia. After the panel cointegration relationship is determined, the direction of causality in the short and long run could be discovered as well. Until now, there is no study about the long-run relationship between these variables in Indonesia, so hopefully, this paper could fill this gap and contribute to explaining the dynamics between oil fuel prices, oil prices, the exchange rates, and agricultural commodity prices in Indonesia.

\section{Oil Fuel Policy and Agricultural Commodities in Indonesia}

Even though the direct link between the energy market and the agricultural market via biofuels production has become a recent issue, in Indonesia this is not the case. Biofuels are not commonly used in that country because they still use fossil fuels. According to the US Energy Information Administration in 2013, $71 \%$ of the total primary energy consumption in Indonesia was fossil fuels, broken down into $30 \%$ for petroleum, $22 \%$ for coal, and $19 \%$ for natural gas. Indonesia is one of the major producers of fossil fuels such as coal, natural gas, and petroleum (Asian Development Bank, 2015). Thus, fossil fuels have been subsidized for citizens in Indonesia for decades because it was feasible to have low domestic prices for these. The idea behind the fossil fuel subsidy programs is to benefit the citizens at cheaper prices. The low and subsidized fossil fuel prices made biofuel consumption in Indonesia drop to zero in early 2015 (Wright, 2016). The fossil fuel subsidy program also holds back an Indonesian sustainable energy system because it discourages the use of much cleaner alternative fuels which are relatively more expensive than the subsidized fossil 
fuel prices (International Energy Agency, 2015). Moreover, the fossil fuel subsidy was always increasing overtime.

Based on the Center for Energy Resources Development Technology report in 2015, the energy subsidy in 2012 reached 306.5 trillion IDR and increased to 453.3 trillion IDR in just a 2 years' span (approximately 23\% increase each year). The fossil fuel subsidies program was bearable when Indonesia was a net oil exporter until 2004. But now, due to growing energy demands and declining production, Indonesia has become a net oil importer (Asian Development Bank, 2015); the local production was not enough to cover all of the energy consumption. Since then, the fossil fuel subsidies have become a huge allocation on the state budget and even bigger than the other public expenditure items which are more important for countries' development such as education, health, and infrastructure. These expenditures are much more beneficial for the citizens compared to the fossil fuel subsidies since most of the Indonesian citizens come from low income households which most of the time could not afford any of these public services by using their own income.

Therefore, considering the fact that the fossil fuel subsidy was an ineffective program, under the regime of the new president, Joko Widodo, Indonesia started to reform its fossil fuel subsidy. Before the policy changed, the price of oil fuel in Indonesia stayed the same for almost 4 years from 2009 until 2013, and it only increased by 10\% from 2013 until 2014. Starting from November 2014, Governments reduced the fossil fuel subsidy for oil fuel (gasoline and diesel) so the oil fuel prices increased significantly (approximately $31 \%$ and $36 \%$ for gasoline and diesel respectively, according to the Asian Development Bank (2015). In January 2015, the entire subsidy for gasoline was removed but the low world oil price at that time caused the gasoline price to decline. The Indonesian government would decide the price of oil fuel (gasoline and diesel) every month based on the new policy from January 2015. But in April 2016, this policy was revised by The Ministry of Energy and Mineral Resources Republic of Indonesia decree no. 39 in 2015, and stated that the minister would decide on the price of the gasoline and diesel every 3 months. In addition, the government also explained the pricing of the oil fuel which would mainly depend on world oil price (especially gasoline), USD-IDR exchange rate, distribution cost, taxes, and the margins of the gas stations as the distributor. PT PERTAMINA ffor Indonesia also had the power to control the price for gasoline and diesel, especially in Java, Madura, and Bali.

The agricultural is a huge sector in Indonesia given that it provided almost $41 \%$ of the total labour force in Indonesia in 2012 \&. As a tropical island that also has fertile soil, Indonesia has a wide range of agricultural commodities. But among all of these, only a few commodities were considered to be the main ones, and with these commodities being called Sembako* ${ }^{* *}$. However, among all of the commodities in the Sembako, there are five commodities that have a huge impact on the national inflation

\footnotetext{
‡ PT PERTAMINA is the state-owned enterprise that is in charge of providing oil (gasoline, diesel, etc).

${ }^{\S}$ From the article in (www.indonesia-investments.com, 2012)

** Sembako is the acronym of sembilan bahan makanan pokok in Indonesian which means nine main agricultural commodities. Sembako is defined in The Ministry of Industry and Trading decree no 115 in 1998 as nine main agricultural commodities which are rice, sugar, cooking oil, meat (beef and chicken), eggs, milk, corn, palm oil, and salt.
} 
in Indonesia; they are rice, sugar, palm oil, beef and red chili (Prastowo et al., 2008).

According to (Prastowo et al., 2008), these agricultural commodity prices movements depend on the production cost or government's regulations for the floor price. In addition, there is also the distribution factor that can influence the price of the agricultural commodities. This factor is the transportation cost from the producer of the commodities (farmers) and consumers in the market. The distribution of these agricultural commodities (sembako) is affecting its price significantly and it still depends a lot on oil fuel. Oil fuel (such as gasoline and diesel) is one of the most popular types in the fossil fuel consumption because of its efficient technology and cheap prices compared to coal and natural gas; the oil fuel is mainly used by road transportation (Center for Energy Resources Development Technology, 2015). This also applies in the agricultural sector since most of these agricultural commodities depend a lot on road transportation. Therefore, the oil fuel is one of the proxies that could be used for the distribution factor in the agriculture sector. The movements from oil fuel might be helpful in forecasting the agricultural commodity prices in Indonesia.

There are only a few studies about the relationship between energy market and agricultural commodities in Indonesia. Abdlaziz et al. (2016) studied the relationship between oil prices and food prices for Indonesia during the 1995-2014 period by using the non-linear autoregressive distributed lag (NARDL) of (Shin et al., 2014). The finding was that there was a strong positive relation between oil price increase and food price in both the short and long run in domestic currency (IDR). It is also shown that the high rate of depreciation of IDR-USD highly impacted the oil price and food price in Indonesia. Prastowo et al. (2008) also researched the impact of the distribution channel to five agricultural commodity prices (rice, palm oil, sugar, beef, and red chili) and inflation. The oil fuel price was used as the distribution channel proxy in this study. The results were that the oil fuel price was not significantly influencing the palm oil and sugar price, but it was significant for rice and red chili. The insignificant result for palm oil and sugar is due to the efficiency of those industries compared to other agricultural commodities. They have permanent distributors (large companies), and therefore they have more efficient distributions. The distribution channel impacted the rice and red chili because the production of these commodities was not permanent; they were usually obtained from small-scale farmers. Therefore, the distribution was not efficient due to an unclear distribution channel in each production. The durability of the commodity was also considered as the reason for strong impact from the distribution because the red chili was a perishable commodity that very much depends on the transportation.

So far, any study about the short and long-run relationship between the oil fuel, oil price, exchange rate, and agricultural commodity prices has not been conducted in Indonesia. Thus, this paper aims to find the relationship between these variables by using the panel cointegration with 5 main agricultural commodity prices during 2014 until 2016 period by following the Nazlioglu \& Soytas (2012) framework.

\section{Methodology}

In order to see the cointegration between the oil fuel prices, oil price, agricultural commodity price, and exchange rate, this study uses the Augmented Dickey Fuller (ADF) unit root test for single time series (oil price, fuel price, and exchange rate) and 
panel unit root for panel data (agricultural prices), panel cointegration and causality analysis. Panel data gives much more information than the usual single time series due to the addition of cross-sectional information. The dimension of cross-sectional in panel data increases the power of the single ADF unit root test. The steps of the analysis are:

1. Conducting the individual unit root test using ADF test for the single series variables and panel root test is conducted for the panel variables. This step is defining whether the variables are suitable for the analysis or not. In this study, two-panel unit root tests will be used for testing unit root for the agricultural commodity prices panel series. They are panel unit root test for homogenous and heterogeneous unit root processes which have been developed by Levin et al. (2002) and Im et al. (2003).

2. After confirming that all variables are series which are integrated to order one in the panel unit root test, the cointegrating relationship can be explored in the cointegration test by Pedroni (1999).

3. Estimating the long-run parameters by using the Fully Modified Ordinary Least Squares (FMOLS) (Pedroni, 2000) and Dynamic Ordinary Least Square (Dynamic-OLS) approaches (Pedroni, 2001). FMOLS accommodates heterogeneity across individual members in the panel by allowing the properties of serial correlation for each member to be different from each other. The group mean panel FMOLS estimator (between-dimension estimators) will be used due to the heterogeneity across the panel members. DOLS have the advantage of allowing for heterogeneity of the cointegrating vectors. The betweendimension estimators also have more interpretation than the within-dimension estimators since the point estimates for between-dimension estimators can stand as the mean value of the cointegrating vectors.

Table 1: List of Variables

\begin{tabular}{clcc}
\hline No. & Commodities Price & Variables & Units \\
\hline 1 & Agricultural Prices & AP & IDR/kg \\
2 & Oil Fuel & OF & IDR/Litre \\
3 & Oil Price & OP & USD/barrel \\
4 & Exchange Rate & ER & IDR/USD \\
\hline
\end{tabular}

4. Determining the causality direction by using a vector error correction model (VECM). The VECM are estimated individually for each agricultural commodity in order to get more specific results. The VECM models that need to be estimated in order to find the causal linkage are:

$$
\begin{aligned}
\Delta \ln A P_{i t}= & \delta_{1 i}+\sum_{p=1}^{k} \delta_{11 i p} \Delta \ln A P_{i t-p}+\sum_{p=1}^{k} \delta_{12 i p} \Delta \operatorname{lnO} O F_{t-p}+ \\
& \sum_{p=1}^{k} \delta_{13 i p} \Delta \ln O P_{t-p}+\sum_{p=1}^{k} \delta_{14 i p} \Delta \ln E R_{t-p}+\phi_{1 i} \hat{\varepsilon}_{i t-1}+v_{1 i t} \\
\Delta \ln O F_{t}= & \delta_{2 i}+\sum_{p=1}^{k} \delta_{21 i p} \Delta \ln A P_{i t-p}+\sum_{p=1}^{k} \delta_{22 i p} \Delta \ln O F_{t-p}+ \\
& \sum_{p=1}^{k} \delta_{23 i p} \Delta \ln O P_{t-p}+\sum_{p=1}^{k} \delta_{24 i p} \Delta \ln E R_{t-p}+\phi_{2 i} \hat{\varepsilon}_{i t-1}+v_{2 i t}
\end{aligned}
$$




$$
\begin{aligned}
\Delta \operatorname{lnOP} t= & \delta_{3 i}+\sum_{p=1}^{k} \delta_{31 i p} \Delta \ln A P_{i t-p}+\sum_{p=1}^{k} \delta_{32 i p} \Delta \ln O F_{t-p}+ \\
& \sum_{p=1}^{k} \delta_{33 i p} \Delta \operatorname{lnOP} P_{t-p}+\sum_{p=1}^{k} \delta_{34 i p} \Delta \ln E R_{t-p}+\phi_{3 i} \hat{\varepsilon}_{i t-1}+v_{3 i t} \\
\Delta \ln E R_{t}= & \delta_{4 i}+\sum_{p=1}^{k} \delta_{41 i p} \Delta \ln A P_{i t-p}+\sum_{p=1}^{k} \delta_{42 i p} \Delta \ln O F_{t-p}+ \\
& \sum_{p=1}^{k} \delta_{43 i p} \Delta \operatorname{lnO} O P_{t-p}+\sum_{p=1}^{k} \delta_{44 i p} \Delta \ln E R_{t-p}+\phi_{1 i} \hat{\varepsilon}_{i t-1}+v_{1 i t}
\end{aligned}
$$

where all the variables can be seen in Table $1, \Delta$ is the first difference operator, $\mathrm{k}$ is the optimal lag length (s) and $\hat{\varepsilon}_{i t}$ is the errors from panel FMOLS estimation. The short-run causality is tested by the Wald test and the long-run causality can be tested by t-test on the error correction parameter (ECT), $\phi_{1 i}$. The significant coefficient of ECT means that oil fuel prices, oil prices, and exchange rate have Granger causality in respect of the agricultural commodity prices in the long run.

5. Conducting the residual diagnostic check was required in order to check whether the VECM was a good model. The valid VECM should have white noise residuals. This means that the residuals should be normally distributed and should not be serially autocorrelated.

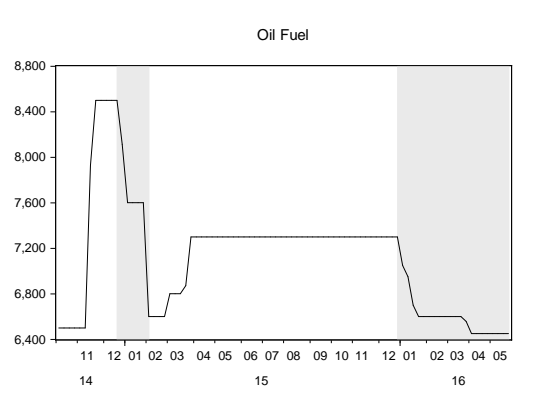

(a)

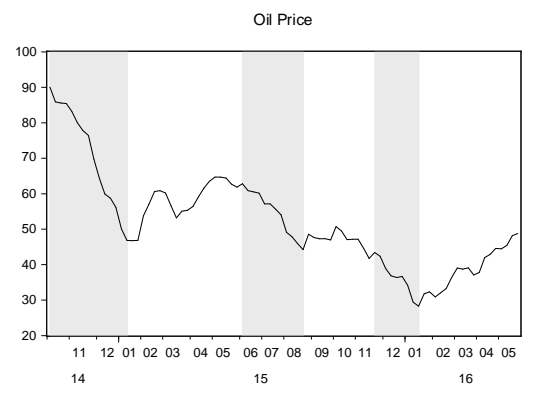

(b)

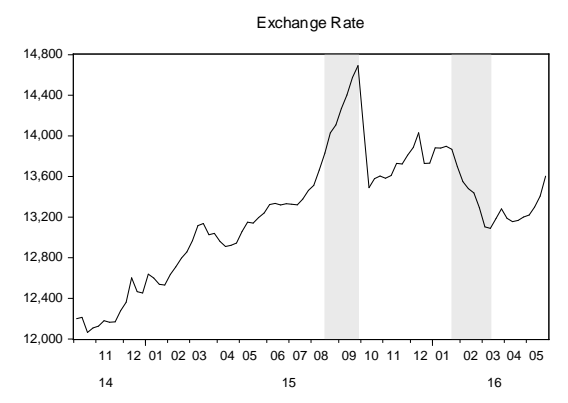

(c)

Figure 1: Series of (a) oil fuel price (b) oil price and (c) exchange rate from the first week of October 2014 - fourth week of May 2016. 


\section{Results}

\subsection{Data and Summary Statistics}

There are four main variables that are used in this study: they are agricultural commodity prices, oil fuel prices, world oil prices, and the USD-IDR exchange rate. The Agricultural commodity price data was collected from The Ministry of Trade, the Republic of Indonesia, and the Oil Fuel Price data from The Ministry of Energy and Mineral Resources Republic of Indonesia. The Brent Oil Price, which is taken from the US Energy Information Administration was used as a proxy for World Oil Price. Jakarta interbank spot dollar rate is the proxy for the exchange rate of USD-IDR and it was collected from the Bank of Indonesia. The list of variables that are used in the model can be seen in Table 1. The agricultural commodities prices (AP) is a weekly panel data with 5 individuals in it, while fossil fuel price, oil price, and exchange rate are a single weekly series for 1 country which is Indonesia. The study focused on the first week of October 2014 until the fourth week of May 2016.

The oil fuel price began to rise in November 2014 as shown in Figure 1(a) because this was the start of the new policy. Starting from this month, the price of the oil fuel became more volatile than before. The oil fuel price also declined for some time as represented by the shaded areas in the figure. This happened from the last week of December 2014 until the first week of February 2015 and again in the last week of December 2015 until the last week of 2016. The oil fuel declines show a similar pattern to the oil price which also declined from October 2014 until mid-January 2014, from mid-May 2015 until August 2015, and from November 2015 until January 2016, as shown in Figure 1(b). The influence of oil price movement in oil fuel pricing is probably the reason they have similar patterns, even though the adjustment sometimes comes later in the oil fuel price.

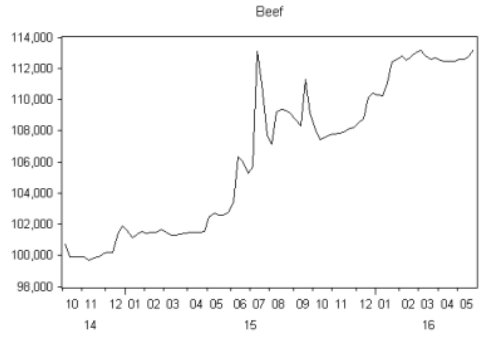

(a)

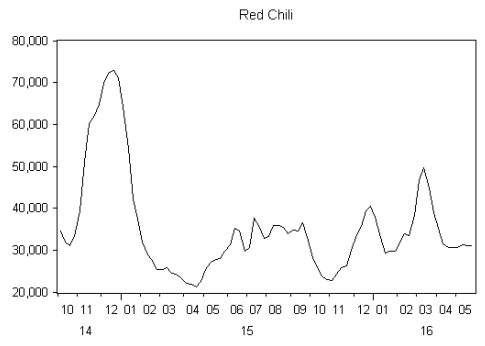

(b)

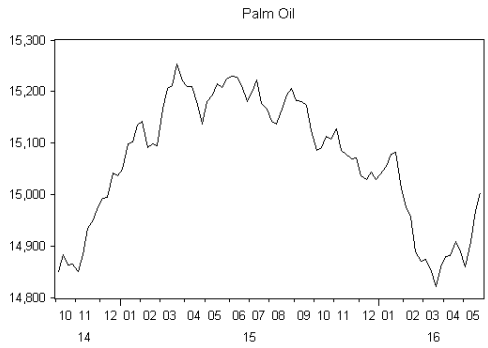

(c)

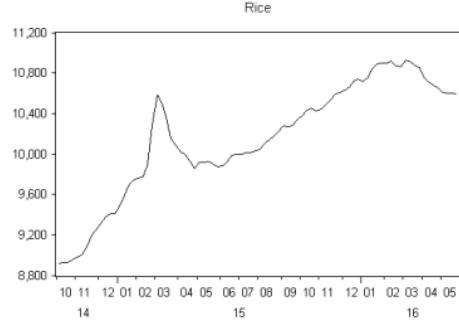

(d)

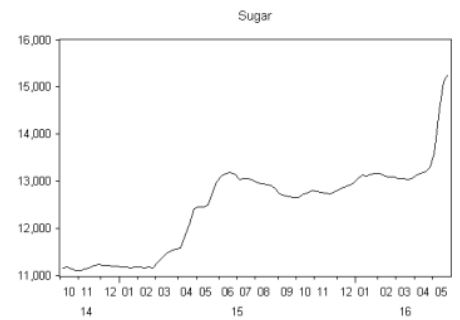

(e)

Figure 2: Agricultural Commodities Prices series. 
The exchange rate showed a pattern of increase from November 2014 until January 2016, as shown in Figure 1(c). There was a steep increase from August 2015 to September 2015. This could be due to the Chinese Yuan devaluation policy on August $11^{\text {th }}, 2015$. The exchange rate was affected negatively by this policy as Indonesia still depends a lot on China in the export and import industry ${ }^{\dagger+}$. But after that, from mid-September 2015 until October 2015, the exchange rate decreased and it seemed to be back on the right track. There was also a decline from the end of January 2016 until March 2016, but it increased again immediately after that.

Table 2: List of individual in the agricultural commodity prices panel

\begin{tabular}{llll}
\hline No. & Commodities Price & Variables & Units \\
\hline 1 & Beef & $-\mathrm{BE}$ & IDR/kg \\
2 & Palm Oil & $-\mathrm{PO}$ & IDR/kg \\
3 & Red Chili Curly & - REC & IDR/kg \\
4 & Rice & - RI & IDR/kg \\
5 & Sugar & SU & IDR/kg \\
\hline
\end{tabular}

The five agricultural commodity prices series can be seen in (d)

(e)

Figure 2 and Table 2. Most of them had a trend of higher prices overtime with quite big differences compared to the previous years, especially in 2016. Beef and rice seemed to be increasing constantly overtime. The price of rice increased quite high in February 2015, this is most likely because, from January 2015, the rice stock in Bulog $¥ \neq$ had decreased constantly until February $2015^{\S \S}$ due to the planting season of rice and the late subsidized rice ${ }^{* * *}$ distribution from November 2014 to February 2015 which caused a shifting rice demand in the market. This condition made the rice price start to increase higher than usual in February 2015 but in April 2015, the rice price seemed to be back on track. Red chili had steep price increases in November 2014 following the oil fuel movements.

Table 3: ADF single series unit root test results

\begin{tabular}{lrrrr}
\hline Variable & \multicolumn{2}{c}{ First difference } \\
\cline { 2 - 5 } & Constant & $\begin{array}{r}\text { Constant } \\
\text { trend }\end{array}$ & Constant & $\begin{array}{r}\text { Constant } \\
\text { trend }\end{array}$ \\
\hline Ln OF & -1.935275 & -2.716890 & $-7.059780^{*}$ & $-7.108368^{*}$ \\
& {$[0.3149]$} & {$[0.2327]$} & {$[0.0000]$} & {$[0.0000]$} \\
Ln OP & -2.122282 & -1.886339 & $-6.061115^{*}$ & $-6.214596^{*}$ \\
& {$[0.2366]$} & {$[0.6528]$} & {$[0.0000]$} & {$[0.0000]$} \\
Ln ER & 1.910758 & -2.064433 & $-6.387668^{*}$ & $-6.508133^{*}$ \\
& {$[0.3260]$} & {$[0.5576]$} & {$[0.0000]$} & {$[0.0000]$} \\
\hline
\end{tabular}

\footnotetext{
${ }^{+\dagger}$ from the article of (www.indonesia-investments.com, 2015)

${ }^{\ddagger}$ BULOG is a state-owned company which is in charge of agricultural commodities (especially sembako) storage and also controlling the floor price for the agricultural commodities in Indonesia.

$\$ \S$ the rice stock had reached 1,3 million tons and it was below the minimum level of 2 million tons.

${ }^{* * *}$ subsidized rice is a product of government's subsidy food program to provide cheap rice for the poor citizens.
} 
Note: ${ }^{*}$ reject the null hypothesis at $1 \%$ significance level.

\subsection{Empirical Analysis}

The analysis began with unit root tests for each variable. All of the variables in the system needed to be integrated of order one in order to be suitable for panel cointegration analysis. First of all, the three single variables (oil fuel, oil price, and exchange rate) were tested by the ADF unit root test. The results of the ADF tests for each variable are shown in Table 3.

The null hypothesis of unit root existence was not rejected for each variable in the level, so there was a unit root in each variable. This can be seen from the $p$-value which is more than $5 \%$. Integration order of the series can be seen by testing unit root in d-differences; the series is said to be integrated to order $d$ if in $d$ differencing series there is no unit root. The null hypothesis was rejected in the first differences ADF test which means that oil fuel price, oil price, and exchange rate were integrated to order one $(d=1)$.

Table 4: Panel unit root test results

\begin{tabular}{lrrrr}
\hline Variable & \multicolumn{3}{c}{ LLC } & IPS \\
\cline { 2 - 5 } & Constant & $\begin{array}{r}\text { Constant } \\
\text { trend }\end{array}$ & Constant & $\begin{array}{r}\text { Constant } \\
\text { trend }\end{array}$ \\
\hline $\ln \mathrm{AP}$ & -1.05612 & -1.12159 & -0.19152 & -1.15216 \\
& {$[0.1455]$} & {$[0.1310]$} & {$[0.4241]$} & {$[0.1246]$} \\
$\Delta \ln A P$ & $-10.4324^{*}$ & $-11.1363^{*}$ & $-12.1946^{*}$ & $-11.8472^{*}$ \\
& {$[0.0000]$} & {$[0.0000]$} & {$[0.0000]$} & {$[0.0000]$} \\
\hline
\end{tabular}

Note: the lag length selection is based on SIC; ${ }^{*}$ reject the null hypothesis at $1 \%$ significance level.

After confirming that all of the single series were I(1), the panel unit root test was then conducted for agricultural commodity prices. The results of the panel test can be seen in Table 4. Both the LLC and IPS panel unit root tests indicated that the AP was a non-stationary series at the level. This means that the null hypothesis of unit root existence in the series cannot be rejected, in the inclusion of constant, or both constant and trend in the model. Next, in order to know the integration order of the series, the panel unit root was also applied in the first differenced series. It turned out that all of the tests rejected the null hypothesis which means that there is no unit root in the series. Therefore, we can conclude that the AP variable is integrated to order one. Looking from the unit root test for single and panel series, the results are fine; from this it could be concluded that all of the variables fulfilled the assumption of panel cointegration analysis.

Table 5: Results for panel cointegration tests

\begin{tabular}{lcc}
\hline Test & constant & Constant and trend \\
\hline Panel v-Statistic & $1.97[0.0244]^{\star *}$ & $0.89[0.1876]^{\star *}$ \\
Panel rho-Statistic & $-0.74[0.2310]$ & $-0.23[0.4079]$ \\
Panel PP-Statistic & $-1.04[0.1491]$ & $-0.90[0.1827]$ \\
Panel ADF-Statistics & $-2.12[0.0171]^{\star *}$ & $-5.75[0.0000]^{\star * *}$ \\
Group rho-Statistic & $0.18[0.5706]$ & $0.59[0.7247]$ \\
Group PP-Statistics & $-0.56[0.2875]$ & $-0.41[0.3394]$ \\
Group ADF-Statistic & $-1.94[0.0260]^{\star *}$ & $-6.86[0.0000]^{\star * *}$ \\
\hline
\end{tabular}


Notes: The lag is selected automatically based on SIC with a maximum lag of 6; ** represents the value is significant at $5 \%$ level and ${ }^{* * *}$ represents the value is significant at $1 \%$ level.

Once all of the variables were confirmed as an I(1) series, the panel cointegration test could be conducted. The results provided in Table 5 showed that two-panel cointegration (within-dimension) test statistics rejected the null hypothesis of no cointegration at least at $5 \%$ significance level, and one group mean (betweendimension) panel cointegration test statistics rejected the null hypothesis of no cointegration when a constant term was included in the model.

Two out of four-panel cointegration test statistics and one group mean panel cointegration test statistics rejected the null when both constant and trend were considered in the model. Three out of seven tests reject the null, even though most of the tests did not reject the null, we still can conclude that the cointegrating relationship exists. This probably happened because from looking at the graph, it can be seen that the series were not similarly moving together.

Table 6: Panel Co-integration Coefficients

\begin{tabular}{|c|c|c|c|c|c|c|}
\hline \multirow{2}{*}{$\begin{array}{l}\text { Commo- } \\
\text { dity }\end{array}$} & \multicolumn{3}{|l|}{ Panel FMOLS } & \multicolumn{3}{|l|}{ Panel DOLS } \\
\hline & Ln OF & Ln OP & Ln ER & Ln OF & Ln OP & Ln ER \\
\hline Beef & $-0.02(-0.44)$ & $-0.01(-0.45)$ & $0.1(1.11)$ & $-0.007(-0.07)$ & $-0.01(-0.38)$ & $0.08(0.75)$ \\
\hline Palm Oil & $0.01(0.93)$ & $0.005(0.75)$ & $0.19(5.84)^{\star * \star}$ & $-0.009(-0.33)$ & $0.01(1.37)$ & $0.22(6.24) * * *$ \\
\hline Red Chili & $2.34(3.32)^{\star * *}$ & $-0.48(-1.67)^{*}$ & $-5.60(-3.97)^{\star \star \star}$ & $2.96(2.19) * \star$ & $-0.66(-1.56)$ & $-6.69(-4.02) * * \star$ \\
\hline Rice & $-0.10(-1.66)$ & $-0.10(-4.11)^{\star \star *}$ & $0.29(2.39)^{\star *}$ & $-0.26(-2.66)^{* * *}$ & $-0.09(-3.15)^{* * *}$ & $0.35(2.85)^{* * *}$ \\
\hline Sugar & $0.09(1.15)$ & $0.17(5.13)^{\star \star \star}$ & $0.39(2.37)^{\star \star}$ & $0.072(0.44)$ & $0.18(3.6)^{* \star *}$ & $0.47(2.39)^{* *}$ \\
\hline \multicolumn{7}{|c|}{ Panel Results } \\
\hline $\begin{array}{l}\text { Between- } \\
\text { dimension }\end{array}$ & $0.47(3.36)^{\star \star \star}$ & $-0.08(0.15)$ & $-0.93(-3.34)^{\star * *}$ & $0.55(2.02)^{\star \star}$ & $-0.12(-1.35)$ & $-1.11(-3.31)^{\star \star *}$ \\
\hline
\end{tabular}

At this stage, group mean (between-dimension) panel FMOLS and DOLS were used to estimate the long-run parameters of the cointegrating relationship. The results of the estimation are provided in Table 6. It can be seen that these two estimators produced similar results in terms of significance of the parameter estimations for each individual and also for the panel. Most of long-run coefficients of oil fuel for each individual in the panel are not significant. The effect of oil fuel was significant only for red chili and rice, either in FMOLS or DOLS estimation.

The oil price long-run coefficients were significant for red chilies, rice and sugar, while the exchange rate affects all of the agricultural commodity prices except beef. Looking at the group mean (between-dimension) panel results, the rise in the oil fuel price would increase the agricultural commodity prices significantly, but a decline in the USD-IDR exchange rate (weak dollar) increased the agricultural commodity prices in the long run. The oil price was not significantly affecting the agricultural commodity prices.

In order to find the direction of the causality between the variables, the causality analysis must be conducted using the VECM. Before the VECM was estimated, first we needed to know the choice of lag for estimating the VECM. The lag length chosen for beef, palm oil, red chili, rice, and sugar are 3, 2, 2, 2 and 2, respectively. The lag length criteria for beef actually suggested 2 as the appropriate lag order, but it turned 
out that the residuals were serially correlated at lag order 2 , so the lag order 3 was chosen for beef. The null hypothesis of the Granger causality test is provided at table 7 and the results of the Granger causality test using the Wald test for the short-run and long-run causality are provided in Table 7.

Table 7: Granger Causality Test results

\begin{tabular}{|c|c|c|c|c|c|c|}
\hline \multirow{2}{*}{$\begin{array}{l}\text { Dependent } \\
\text { Variable }\end{array}$} & \multicolumn{4}{|c|}{ Short run causality } & \multicolumn{2}{|c|}{ Long Run causality } \\
\hline & $\Delta \ln A P_{i}$ & $\Delta \ln O F$ & $\Delta \ln O P$ & $\Delta \ln E R$ & $E C T_{i t-1}$ & t-statistic \\
\hline \multicolumn{7}{|l|}{ Beef [i=1] } \\
\hline$\Delta \ln A P_{1}$ & - & $0.13(0.94)$ & $0.59(0.63)$ & $0.23(0.87)$ & -0.18 & {$[-1.91]$} \\
\hline$\Delta \ln O F$ & $0.15(0.93)$ & - & $0.68(0.57)$ & $0.20(0.90)$ & 0.06 & [ 0.21] \\
\hline$\triangle \ln O P$ & $0.12(0.88)$ & $1.88(0.16)$ & - & $0.01(0.99)$ & -0.24 & {$[-0.52]$} \\
\hline$\Delta \ln E R$ & $1.49(0.23)$ & $0.26(0.77)$ & $0.56(0.58)$ & - & 0.06 & [ 0.69] \\
\hline \multicolumn{7}{|c|}{ Palm Oil [i=2] } \\
\hline$\Delta \ln A P_{2}$ & - & $0.07(0.93)$ & $3.30(0.04)^{\star *}$ & $0.27(0.76)$ & -0.04 & {$[-0.95]$} \\
\hline$\Delta \ln O F$ & $0.39(0.68)$ & - & $0.39(0.69)$ & $0.20(0.82)$ & -0.88 & {$[-1.17]$} \\
\hline$\triangle \ln O P$ & $0.73(0.48)$ & $1.33(0.27)$ & - & $0.17(0.84)$ & 1.82 & {$[1.56]$} \\
\hline$\Delta \ln E R$ & $3.15(0.05)^{\star *}$ & $0.17(0.85)$ & $1.28(0.28)$ & - & 0.31 & [ 1.43] \\
\hline \multicolumn{7}{|c|}{ Red Chili [i=3] } \\
\hline$\Delta \ln A P_{3}$ & - & $0.90(0.41)$ & $0.30(0.74)$ & $0.68(0.51)$ & -0.09 & {$[-2.13]^{\star *}$} \\
\hline$\Delta \ln O F$ & $4.05(0.02)^{\star \star}$ & - & $0.38(0.68)$ & $0.01(0.99)$ & 0.01 & {$[0.76]$} \\
\hline$\triangle \ln O P$ & $1.45(0.24)$ & $1.26(0.29)$ & - & $0.43(0.65)$ & -0.03 & {$[-1.15]$} \\
\hline$\Delta \ln E R$ & $1.52(0.23)$ & $0.24(0.79)$ & $0.25(0.78)$ & - & -0.003 & {$[-0.62]$} \\
\hline \multicolumn{7}{|l|}{ Rice [i=4] } \\
\hline$\Delta \ln A P_{4}$ & - & $0.08(0.92)$ & $1.48(0.23)$ & $0.83(0.44)$ & -0.12 & {$[-3.52]^{\star \star *}$} \\
\hline$\Delta \ln O F$ & $0.30(0.74)$ & - & $0.10(0.91)$ & $0.27(0.77)$ & -0.03 & {$[-0.16]$} \\
\hline$\Delta \ln O P$ & $1.46(0.24)$ & $1.44(0.24)$ & - & $0.06(0.94)$ & -0.10 & {$[-0.32]$} \\
\hline$\Delta \ln E R$ & $0.39(0.67)$ & $0.12(0.89)$ & $0.17(0.84)$ & - & 0.03 & {$[0.46]$} \\
\hline \multicolumn{7}{|l|}{ Sugar $[i=5]$} \\
\hline$\Delta \ln A P_{5}$ & - & $0.11(0.89)$ & $0.20(0.81)$ & $0.14(0.87)$ & -0.09 & {$[-2.52]^{\star *}$} \\
\hline$\Delta \ln O F$ & $0.09(0.92)$ & - & $0.13(0.87)$ & $0.17(0.84)$ & -0.16 & {$[-1.01]$} \\
\hline$\Delta \ln O P$ & $0.56(0.58)$ & $1.61(0.21)$ & - & $0.02(0.98)$ & 0.15 & {$[0.61]$} \\
\hline$\Delta \ln E R$ & $0.28(0.75)$ & $0.41(0.66)$ & $0.45(0.64)$ & - & 0.05 & [1.13] \\
\hline
\end{tabular}

Notes: the lag length used for the beef prices, palm oil prices, red chili prices, rice prices, and sugar prices are 3,2, 2, 2, and 2 respectively. The values in the table are the result of partial F-statistics from testing the imposed coefficient of the lagged regressors in the short-run causality and coefficient for ECT. Inside the bracket () is the p-value. ${ }^{* *}$ and ${ }^{* * *}$ indicate that the null is rejected at $5 \%$ and $1 \%$ level respectively.

The long-run causality could be seen from the ECT coefficient. The ECT for red chili, rice, and sugar were significant and they all have negative coefficient which means the model are below the equilibrium value. The red chili, rice and sugar prices disequilibrium will be corrected each week as much as $0.09,0.12,0.09$ percentage points respectively. This indicated that there is cointegrating relationships in each red chili, rice and sugar prices with the oil fuel prices, oil prices, and the exchange rate in the long run.

It can be seen from the test results that in the short-run causality analysis, the oil prices, palm oil prices, and red chili prices had a unidirectional causality to palm oil prices, exchange rate, and oil fuel prices respectively in the short run. This showed that the oil prices were affecting the palm oil prices in the short run. In the long-run causality analysis, it was shown that the oil fuel prices, oil prices, and exchange rate 
altogether had Granger causality effect on the red chili prices, rice prices, and sugar prices which means that these variables (oil fuel prices, oil prices, and exchange rate) were indeed having an impact on most of the agricultural commodity prices in the long run.

After estimating the VECM, the diagnostic check for the residuals was needed to be undertaken in order to make sure that the residuals are white noise. If the residuals are not white noise, then this could be a sign that the VECM were mis-specified which could lead to the wrong results or interpretation.

The test for the residuals is shown in Table 8. The Breusch-Godfrey LM tests were used to check for serial autocorrelation and the Jarque Berra normality test was used in order to see if the residuals are normally distributed. All of the residuals seemed to not be serially correlated. However, the Jarque Berra test indicated that all of the residuals are not normal. This result is expected because of the outliers in the residuals. The dummy variables were also fitted in the VECM model to correct these residuals, but this also did not improve the diagnostic results. However, all of the residuals are serially uncorrelated so it could be concluded that the residuals were white noise.

Table 8: Residual diagnostic checking tests

\begin{tabular}{cllll}
\hline Dependent Variable & \multicolumn{3}{l}{ White Noise Tests } & \\
\cline { 2 - 5 } & BG LM(1) & BG LM(7) & BG LM (12) & Jarque Berra \\
\hline Beef [i=1] & & & & \\
$\Delta \ln A P_{1 t}$ & 0.057 & 0.051 & 0.006 & 0.000 \\
$\Delta \ln O F_{t}$ & 0.157 & 0.520 & 0.229 & 0.000 \\
$\Delta \ln O P_{t}$ & 0.867 & 0.090 & 0.194 & 0.000 \\
$\Delta \ln E R_{t}$ & 0.479 & 0.728 & 0.682 & 0.000 \\
Palm Oil [i=2] & & & & \\
$\Delta \ln A P_{2 t}$ & 0.829 & 0.279 & 0.083 & 0.000 \\
$\Delta \ln O F_{t}$ & 0.742 & 0.601 & 0.245 & 0.000 \\
$\Delta \ln O P_{t}$ & 0.781 & 0.121 & 0.345 & 0.000 \\
$\Delta \ln E R_{t}$ & 0.207 & 0.704 & 0.861 & 0.000 \\
Red Chili [i=3] & & & & \\
$\Delta \ln A P_{3 t}$ & 0.377 & 0.581 & 0.212 & 0.000 \\
$\Delta \ln O F_{t}$ & 0.589 & 0.591 & 0.300 & 0.000 \\
$\Delta \ln O P_{t}$ & 0.998 & 0.049 & 0.124 & 0.001 \\
$\Delta \ln E R_{t}$ & 0.246 & 0.834 & 0.948 & 0.000 \\
Rice [i=4] & & & & \\
$\Delta \ln A P_{4 t}$ & 0.499 & 0.527 & 0.341 & 0.000 \\
$\Delta \ln O F_{t}$ & 0.927 & 0.538 & 0.081 & 0.000 \\
$\Delta \ln O P_{t}$ & 0.960 & 0.037 & 0.109 & 0.000 \\
$\Delta \ln E R_{t}$ & 0.204 & 0.794 & 0.853 & 0.000 \\
$\Delta \ln A P_{5 t}$ & 0.841 & 0.451 & 0.765 & 0.000 \\
$\Delta \ln O F_{t}$ & 0.417 & 0.695 & 0.237 & 0.000 \\
$\Delta \ln O P_{t}$ & 0.635 & 0.102 & 0.276 & 0.022 \\
$\Delta \ln E R_{t}$ & 0.317 & 0.729 & 0.793 & 0.000 \\
Sugar [i=5] & & &
\end{tabular}

Notes: the values provided in this table are the p-value from the tests.

\section{Discussion and Policy Implications}

Further comments on the results are presented in this section. In addition to the commenting, the shortcomings of the analysis are also discussed. In section 6 , it can 
be seen that all of the variables are integrated to order one $(\mathrm{I}(1))$, so the assumptions for panel cointegration analysis were fulfilled. The panel cointegration test also indicated that there is a cointegration relationship between oil fuel prices, oil prices, exchange rate and agricultural commodity prices, both in the within-dimension and in the group mean dimension panel cointegration tests.

Moving to the long-run parameter estimation part which is the main part of our findings, in line with the literature, rice and red chili are commodities that are affected by oil fuel price significantly, which means the information on oil fuel prices can be helpful in forecasting the red chili and rice in the long run due to their long distribution chains. But here, oil fuel prices positively affected red chili but not for rice. This result contrasts with the literature which stated that the increasing oil fuel prices would increase the agricultural commodity prices (cost-push in transportation cost). This seemed to be happening because the movements of rice were much more affected by supply and demand of rice or the international price of rice (Syafa'at, 2007). The Indonesian Government has its own regulations on rice pricing which are not based only on oil fuel but also depends on Bulog regulations. Despite the fact that the oil fuel prices decreased after December 2014, the rice price continued to increase until March 2016. So, this might be one of the reasons for the negative coefficient in the long-run parameter estimations; the effect from the indirect distribution factor was not large enough compared to the price regulations that needed to be followed at that time.

The beef price almost had the same increasing pattern as rice, and the result showed that there is a negative impact from the oil fuel price to the beef price in the long-run parameter estimation even though it is not significant. The oil fuel price did not have a significant impact in the beef price; this could be due to the beef transactions that usually take place locally so the distribution factor (oil fuel prices) does not affect the beef price significantly (Prastowo et al., 2008). The palm oil and sugar were also not affected by the oil fuel price significantly in the long run. Thus, these results confirm the findings of the Prastowo et al. (2008) that different from the three commodities above (rice, red chili, and beef), palm oil and sugar are produced efficiently by huge companies so the distribution factor does not really affect much the prices of sugar and palm oil.

Some coefficients in the long-run parameter estimation for individual agricultural commodities had mixed results. For the exchange rates, only red chili had a positive impact from the weak USD, but the rest of the commodities were negatively affected by the weak dollar (strong IDR) although only by a very small coefficient. This might happen due to a difference in supply and demand for each commodity, because supply and demand influences most of the volatility in the agricultural price.

In the group mean panel estimation result, the findings also showed that the oil fuel prices and exchange rate had a long-run impact on agricultural commodity prices. This means that the policy makers, investors and traders who are focusing on the agricultural sector in Indonesia need to consider about the dynamics of the oil fuel prices and also the exchange rates when deciding on their strategies in the long run. As these two variables were clearly contributing to the agricultural commodity prices, so they will help in forecasting the agricultural commodities' movements.

However, the results of the oil prices on agricultural commodities in Indonesia 
supports the neutrality hypothesis that the world oil prices had nothing to do with the local agricultural prices. This could probably happen because the agricultural commodities in Indonesia do not have any direct link with the world oil prices, as biofuel consumption is still an uncommon practice in Indonesia due to the cheaper price of its oil fuel. This also shows that the indirect channel via local oil fuel prices between the energy market and agricultural market matters more in the case of Indonesia.

In the case of causality analysis, the results showed that the oil fuel prices had a unidirectional causality to the palm oil price in the short run. The palm oil prices had a Granger causality relationship to the exchange rate and the red chili prices had a Granger causality effect in respect of the oil fuel prices in the short run as well. And in the long run, the oil fuel prices, oil prices, and exchange rate had a Granger causality effect in respect of all of the agricultural commodities except for the beef prices and palm oil prices. Now the oil prices are also considered to contribute to the long-run relationship for the red chili, rice, and sugar, so this is in line with the estimation of the long-run parameters which had the same conclusion that oil price affected these agricultural commodities. The residual diagnostic check was conducted in order to specify that the VECM is the right model. The residuals of the VECM need to be serially uncorrelated and normally distributed (white noise) in order to pass the diagnostic check as a valid model.

The residual diagnostic check for the VECM indicated that they were white noise. The main problem of the model is that most of the residuals from the VECM model had outlier problems. The inclusion of the dummy variable in order to get rid of these outliers also could not solve this problem. But the residuals are serially uncorrelated so the result of causality analysis (VECM) are still valid.

The most important finding in this study is that oil fuel prices and exchange rate affect the forecasting of the agricultural commodity prices in the long-run. Moreover, the oil fuel prices, world oil prices, and exchange rates altogether had a Granger causality to red chili prices, rice prices, and sugar prices. This implies that the oil fuel prices, world oil price, and exchange rates could improve the forecast of agricultural commodity prices. The good timing for investing in the agricultural market in Indonesia is when the USD weakens towards IDR and when the fuel prices are decreasing, which was the case in December 2014 - May 2016. The world oil prices might have a contribution in respect of the local agricultural commodities. Nazlioglu \& Soytas (2012) had proven that world oil prices have a uni-direction causality relationship to the world agricultural commodity prices, which is one of the factors that influenced the local agricultural commodities in Indonesia. This link could be examined for further study in the future in order to confirm how large the impact is of the world to local agricultural commodity prices.

However, there are some limitations identified in this study. There were outlier problems in the VECM residuals and these outliers occur probably due to the shock and structural shift that occurred exclusively in each agricultural commodity prices and did not occur in the oil fuel prices, oil prices, and exchange rates. Probably other variables such as the supply and demand of these agricultural commodities could be included in the model and they would make a better fit for the VECM model. A second drawback was the limited number of agricultural commodities used in the study. Wider 
agricultural commodities prices might give more reliable results in the panel cointegration and causality analysis, so it is better to increase the number of representative agricultural commodities to be included for further study. Even though more agricultural commodities could produce more reliable results, this might also have a problem of cross-section dependency among the commodities in the panel, which breaks the assumption of Pedroni (1999) which does not allow for crosssectional dependency. Third, this study also did not consider the presence of the structural breaks in the series. The wrong results might be obtained if there are such structural breaks. In order to solve this problem, instead of using the Pedroni (1999) test, the Banerjee \& Carrion-i-Silvestre (2015) method can be used as it allows for the panel data cointegration test with structural breaks and cross-section dependence. A longer time period is also suggested in order to yield more generalized results for a longer period of time.

\section{Conclusions}

This paper provided the analysis of the relationships between oil fuel prices, oil prices, exchange rates, and agricultural commodity prices in Indonesia by utilizing the panel cointegration and Granger causality analysis on a panel of five main agricultural commodities (rice, red chili, beef, palm oil, and sugar). The findings in the study showed clear evidence of oil fuel price and exchange rate's impact on the agricultural commodities prices. Moreover, the causality analysis shows that in the long run, the oil fuel price, oil price, and the exchange rate had unidirectional causality to all of the agricultural commodity prices except for beef and palm oil prices. This is again in line with the literature that the oil fuel price, oil price, and the exchange rate has a unidirectional causality to most of the agricultural commodity prices.

In order to make an improvement in the agriculture sector, the policy makers in this sector need to consider the information from the oil fuel prices, oil prices and exchange rates in order to improve their forecasting of the agricultural commodity prices. The government needs to consider the prices of oil fuel, oil, and the exchange rate in order to stabilize the price in the agricultural commodity prices in Indonesia. Investors and traders in the agricultural sector should also take into account the information from the oil fuel prices, oil prices, and exchange rates when designing their investment strategies in the long run. In order to have more reliable results, other variables such as supply and demand of these agricultural commodities could be included in the VECM (Granger causality model) or the use of another model specification which allows for structural shifts and shocks. There is also room for improvement for further research; a wider range of agricultural commodities can be used and a longer time span of the study is also suggested in order to have more reliable results.

\section{References}

Abdlaziz, R. A., Rahim, K. A., \& Adamu, P. (2016). Oil and Food Prices Co-integration Nexus for Indonesia: A Non-linear Autoregressive Distributed Lag Analysis. 6(1): 82-87. 
Adämmer, P., \& Bohl, M. T. (2015). Speculative bubbles in agricultural prices. The Quarterly Review of Economics and Finance, 55: 67-76. https://doi.org/10.1016/j.qref.2014.06.003

[ADB] Asian Development Bank. (2015). Fossil fuel subsidies in indonesia-Trends, impacts, and reforms. Asian Development Bank.

Banerjee, A., \& Carrion-i-Silvestre, J. L. (2015). Cointegration in Panel Data with Structural Breaks and Cross-Section Dependence: COINTEGRATION IN PANEL DATA. Journal of Applied Econometrics, 30(1): 1-23. https://doi.org/10.1002/jae.2348

Center for Energy Resources Development Technology. (2015). Indonesia Energy Outlook 2015. Center for Energy Resources Development Technology.

Ciaian, P., \& Kancs, d'Artis. (2011). Interdependencies in the energy-bioenergy-food price systems: A cointegration analysis. Resource and Energy Economics, 33(1): 326-348. https://doi.org/10.1016/j.reseneeco.2010.07.004

de Gorter, H., \& Drabik, D. (2016). Biofuel policies and the impact of developing countries' policy responses to the 2007-2008 food price boom. Global Food Security, 11: 64-71. https://doi.org/10.1016/j.gfs.2016.07.008

Gardner, B. (2007). Fuel Ethanol Subsidies and Farm Price Support. Journal of Agricultural \& Food Industrial Organization, 5(2): 1-22. https://doi.org/10.2202/1542-0485.1188

Harri, A., Nalley, L., \& Hudson, D. (2009). The Relationship between Oil, Exchange Rates, and Commodity Prices. Journal of Agricultural and Applied Economics, 41(2): 501-510. https://doi.org/10.1017/S1074070800002959

Im, K. S., Pesaran, M. H., \& Shin, Y. (2003). Testing for unit roots in heterogeneous panels. Journal of Econometrics, 115(1): 53-74. https://doi.org/10.1016/S03044076(03)00092-7

International Energy Agency. (2015). Indonesia 2015. International Energy Agency.

Kwon, D.-H., \& Koo, W. W. (2009). Price Transmission Channels of Energy and Exchange Rate on Food Sector: A Disaggregated Approach based on Stage of Process. Presented at the the Agricultural \& Applied Economics Association 2009, Milwaukee, Wisconsin.

Levin, A., Lin, C.-F., \& Chu, C.-S. J. (2002). Unit root tests in panel data: Asymptotic and finite-sample properties. Journal of Econometrics, 108(1): 1-24.

Nazlioglu, S. (2011). World oil and agricultural commodity prices: Evidence from nonlinear causality. Energy Policy, 39(5): 2935-2943. https://doi.org/10.1016/j.enpol.2011.03.001

Nazlioglu, S., \& Soytas, U. (2012). Oil price, agricultural commodity prices, and the dollar: A panel cointegration and causality analysis. Energy Economics, 34(4): 1098-1104. https://doi.org/10.1016/j.eneco.2011.09.008 
Pedroni, P. (1999). Critical values for cointegration tests in heterogeneous panels with multiple regressors. Oxford Bulletin of Economics and statistics, 61(S1): 653-670.

Pedroni, P. (2000). Fully modified OLS for heterogeneous cointegrated panels. In Advances in Econometrics (Vol. 15, pp. 93-130). Emerald (MCB UP ). https://doi.org/10.1016/S0731-9053(00)15004-2

Pedroni, P. (2001). Purchasing Power Parity Tests in Cointegrated Panels. Review of Economics and Statistics, 83(4), 727-731. https://doi.org/10.1162/003465301753237803

Prastowo, N. J., Yanuarti, T., \& Depari, Y. (2008). Pengaruh distribusi dalam pembentukan harga komoditas dan implikasinya terhadap inflasi. The Effect of Distribution on Commodity Pricing and Its Implications for Inflation. Working Paper, WP/07/2008. Jakarta (ID): Bank Indonesia.

Shin, Y., Yu, B., \& Greenwood-Nimmo, M. (2014). Modelling asymmetric cointegration and dynamic multipliers in a nonlinear ARDL framework. In Festschrift in honor of Peter Schmidt (pp. 281-314). Springer.

Syafa'at, N. (2007). Matrik Kebijakan Perberasan di Negara Asia [The Matrix of Rice Policy in Asia]. Pusat Analisis Sosial Ekonomi dan Kebijakan Pertanian badan Penelitian dan Pengembangan Pertanian Departemen Pertanian. Jakarta (ID): Departemen Pertanian.

Wright, T. (2016). Biofuels Annual Indonesia Biofuels Annual 2016. Jakarta (ID): United States Department of Agriculture.

Yu, T.-H., Bessler, D. A., \& Fuller, S. (2006, July 23). Cointegration and Causality Analysis of World Vegetable Oil and Crude Oil Prices. American Agricultural Economics Association Annual Meeting.

Zhang, Q. (2008, February 2). Examining the Impact of the World Crude Oil Price on China's Agricultural Commodity Prices: The Case of Corn, Soybean, and Pork. Agricultural Economics Association Annual Meetings. 